\title{
Regulatory framework of teaching geography and economy in the Bulgarian school in the new curricula
}

\section{Yeni müfredatta Bulgar okulunda coğrafya ve ekonomi öğretimi için düzenleyici çerçeve}

\author{
Prof. Stella Dermendzhieva, $\mathrm{PhD}^{1}$ (D), Assoc. Prof. Petya SABEVA, PhD² (D, \\ Chief Assist. Tamara Draganova, $\mathrm{PhD}^{3}$ (D)
}

1"St. Cyril and St. Methodius" University of Veliko Tarnovo, Department of Geography, Veliko Tarnovo, Bulgaria

2"St. Cyril and St. Methodius" University of Veliko Tarnovo, Department of Geography, Veliko Tarnovo, Bulgaria

3"St. Cyril and St. Methodius" University of Veliko Tarnovo, Department of Geography, Veliko Tarnovo, Bulgaria

ORCID: S.D. 0000-0002-5963-6631; P.S. XXXX-XXXX-XXXX-XXXX; T.D. 0000-0003-1405-5638

\section{ABSTRACT}

The educational reform, which is being implemented step-by-step in Bulgaria during the last three school years, is a projection of the vision of the necessity to change at all levels: normative (state educational standards, curricula and school programs, training kits), institutional and didactic-methodical. In particular, a procedural - regulatory framework determines the school geographic education in Bulgaria. The starting point of the study is the situational analysis of the regulated learning of knowledge and the formation of skills and competences in geography and economics's training.

Expected empirical results link sustained traditional models with innovative didactic solutions to school geography training. Essentially, reforming processes determine new educational practices as they create objective conditions for adapted to the modernity geographical training. The situational analysis of the normative documentation regulates the assimilation of knowledges, skills and competences in geography and economics training that is constructed and conformed to the European reference framework of education.

Education in the country is a national priority and as such is realized in accordance with the principles of right and access to quality school education, the interest and motivation of the students towards their age and social changes in life but also with the possibility to apply the acquired competencies in practice. The new realities require the preservation and development of the Bulgarian educational tradition, the validation of innovation and efficiency in pedagogical practices and the organization of the educational process on the basis of scientific substantiation and prognosis of the results of the innovations. Keywords: curricula, situational analysis, geography and economy.

\section{Öz}

Bulgaristan'da son üç okul yılında adım adım uygulanmakta olan eğitim reformu, her seviyede değişme zorunluluğu vizyonunun bir yansımasıdır: normatif (devlet eğitim standartları, müfredat ve okul programları, eğitim setleri) kurumsal ve didaktik-metodik. Özellikle, prosedürel bir düzenleme çerçevesi, Bulgaristan'daki okul coğrafi eğitimini belirler. Çalışmanın başlangıç noktası, düzenlenmiş bilgi öğreniminin durumsal analizi ve coğrafya ve ekonomi eğitiminde beceri ve yeterliliklerin oluşumu. Beklenen deneysel sonuçlar, sürdürülebilir geleneksel modelleri okul coğrafya eğitimine yenilikçi didaktik çözümlerle ilişkilendirmektedir. Temel olarak, reform süreçleri modernite coğrafi eğitimine adapte edilmek için nesnel koşullar yarattıkları için yeni eğitim uygulamalarını belirler.

Normatif dokümantasyonun durum analizi, coğrafi eğitim ve ekonomi eğitiminde Avrupa eğitim çerçevesine uygun olarak yapılandırılmış ve uyarlanmış bilgi, beceri ve yetkinliklerin asimilasyonunu düzenlemektedir.

Ülkede eğitim ulusal bir önceliktir ve bu nedenle kaliteli okul eğitimine hak ve erişim ilkeleri, öğrencilerin yaşlarına ilgileri ve motivasyonları, yaşamdaki sosyal değişimlere ve aynı zamanda uygulama imkânlarına uygun olarak gerçekleştirilir. uygulamada edinilmiş yeterlilikler. Yeni gerçeklikler, Bulgar eğitim geleneğinin korunmasını ve geliştirilmesini, pedagojik uygulamalarda inovasyonun ve verimliliğin onaylanmasını ve inovasyonların sonuçlarının bilimsel kanıtı ve prognozu temelinde eğitim sürecinin organizasyonunu gerektirir.

Anahtar Sözcükler: program, durum analizi, coğrafya ve ekonomi.

Submitted/Başvuru: 15.03.2019 Accepted/Kabul: 05.05.2019

Corresponding author/Sorumlu yazar: Stela DERMENDZHIEVA / stela.dermendzhieva@mail.bg

Citation/Atıf: Dermendzhieva,S., Sabeva, P., Draganova, T.(2019). Regulatory framework of teaching geography and economy in the Bulgarian school in the new curricula. In B. Gonencgil, T. A. Ertek, I. Akova ve E. Elbasi (Eds.), 1st Istanbul International Geography Congress Proceedings Book (pp. 1102-1109). Istanbul, Turkey: Istanbul University Press. https://doi.org/10.26650/PB/PS12.2019.002.102 


\section{INTRODUCTION}

„The politicians build states, the teachers build modern minds".

B. Fonlon

The new educational realities in Bulgaria - law, ordinances, school plans and curricula define the school framework of geographical education. The educational reform, which has been realized in stages in Bulgaria in the last school years, is a projection of a vision for the need to change at all levels: normative (state educational standards, teaching plans and curricula, educational set), institutional and didactic-methodical. It raises a number of questions to which we are looking for answers about the place and role, importance and content of the school geographical education and its successful development against the background of a unified state educational policy. It is also a circumstance that defines a new school environment with adapted educational phenomena, processes and objects.

In particular, the procedural and normative framework determines the school geographical education in Bulgaria. The starting point of the study is the situational analysis of the regulated knowledge acquisition and formation of skills and competences in the training of geography and economics in the junior high school stage in grades $5-7$. Expected empirical results links sustainably imposed traditional models with innovative didactic solutions to school geographic training. Essentially, the reform processes determine new educational practices because they create objective conditions for geographic training that is adaptable to modern times.

The modernity of school education - respectively the geography in junior high school for grades 5 - 7. - is not (only) expressed in computerization, technology and mechanical borrowing of successful experience from foreign educational practices. It is a way of thinking. It is an attitude about what is happening behind the walls of the classroom. It is the professional life of a teacher, marked by complex, unpredictable and emotionally charged situations.

At the same time, the training is summoned to match students' naturally innate curiosity at a time when the geographical information is plentiful and easily accessible but too dynamic. From geography as a subject is expected to provide an „intellectual key” to its perception, comprehension and its use in specific life decisions. Or to put it another way - geography should make the world more accessible for the learners.

\section{NORMATIVE FRAMEWORK OF GEOGRAPHY AND ECONOMY TRAINING}

With the new educational law - the Pre-school and school education law from 2016 and the ordinance No. 4 on the school plan (which defines the state educational standard for the teaching/school plan as a new educational document) set the framework requirements for the characteristics, content and structure of the school plan (ZPUO, 2015).

The framework school plans defines the number of school weeks of classes, the name of the school subject, the annual number of school hours for the class, and the total number of stages and degrees. In the structure of the school plan the study of geography and economics is included in the compulsory school lessons. The general education preparation is carried out by studying 20 school subjects in the nine groups of key competences.

The theoretical concepts are linked to the educational documentation through a constructive analysis of the normative framework, which presumably expresses the concept of the parameters of the contemporary geographic education in the Bulgarian school. The most in-depth is he at the curriculum level.

The curriculum fits in, continues, develops and arguments from by the philosophy of the integrative nature of the curriculum content and the resulting didactic learning opportunities and value orientations (relationships) related to the core competencies set out in the law and in the documents specifying it.

The curricula are an expression of the vision of social expectations for the quality of ,education” on the one hand, and on the other - they determine the parameters of the educational process by subjects and classes. They are a compulsory for application operational document, but in the context of the new ideas for stimulating teacher creativity, student - centered training, and lifelong learning - they should only be seen as a framework that sets the standard and general parameters of the content scope. They have the functional characteristics of a content, structural and didactic „measure” against the compilers of textbooks and school aids, as well as of all external control formats, in order to have a stable objective basis for the comparability of the results. 
At the same time, the teacher is provided with the didactic freedom to place the accents on the topics and to choose the specific technology for teaching the school content in order to provoke the cognitive activity of the students, respectively to achieve the expected results of the geographical training. Considering all these variables, the curricula can be interpreted as a stimulus rather than a barrier to the opportunity to develop a teacher's professional initiative, depending on his/her competence and style, tailored to the individual characteristics of the students and the opportunities which offer the particular school environment.

Last but not least, the curricula can be assessed as a resource for overcoming the academic character of the school training and for building a link between the school content and the ever-changing reality that surrounds the students.

Based on the requirements, a curriculum for each class that defines the training objectives, school content and training results of the respective class has the following structure - figure 1.
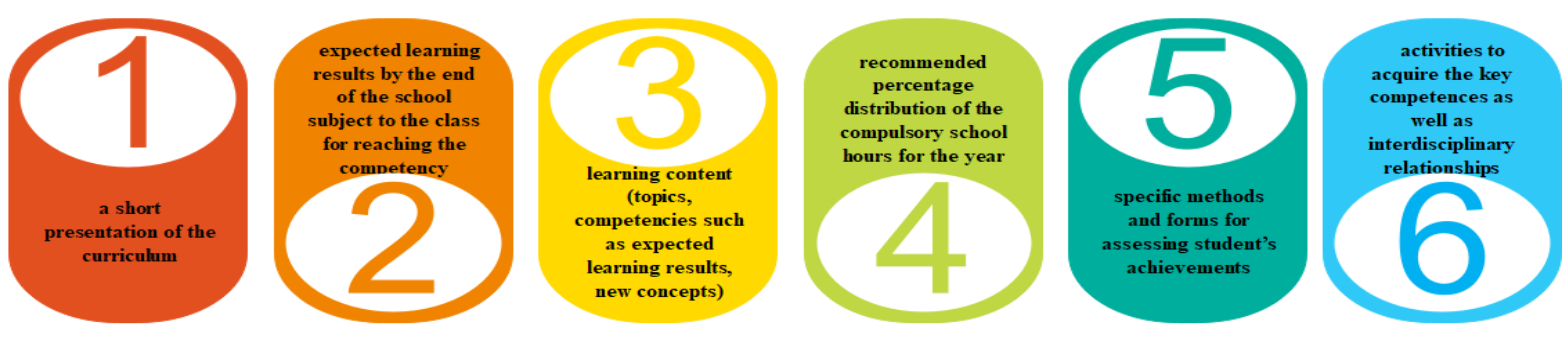

Figure 1: Structure of curriculum in geography and economics

What are our motives? The empirical observations prove that too often the formalism of the educational documentation is obvious, which meaningless the rationality of its content. The system - forming character, the logic and the derived key characteristics of geographical knowledge in each training course must be interpreted critically, depending on the teacher's individually fixed target trajectory and the specifics of the educational environment. They are the most constant pillars on which the ideological decisions for the realization of the training as a whole and for each individual unit in particular are based.

The Geography of continents and oceans course is one of the most dynamically changing positions in the concept for vision and content of the geographical education under any reform. The time localization has been modified many times, the content scope (complex or differentiated by the natural - geographical and socio - economic part), the order of study of continents and oceans. If a sample of several curricula is followed in the relatively recent history of geographical education the support for the claim is obvious - table 1 .

Table 1: A comprehensive overview of curricula in Geography and economics

\begin{tabular}{|c|c|}
\hline $\begin{array}{l}\text { Curricula } \\
\text { (by selected years) }\end{array}$ & $\begin{array}{l}\text { Geography of continents and oceans } \\
\text { (training courses by classes) }\end{array}$ \\
\hline 1925 & $\begin{array}{l}\text { I. (now 5th grade) - General physical (natural) geography. Geography of Africa and Australia } \\
\text { II. (now 6th grade) - Geography of the other continents. }\end{array}$ \\
\hline 1945 & $\begin{array}{l}\text { Il. (now } 6 \text { th grade) - Physical (natural) geography of the continents } \\
\text { V. (now } 9 \text { class) - Physical (natural) geography of the continents. }\end{array}$ \\
\hline 1964 & $\begin{array}{l}\mathbf{5}^{\text {th }} \text { grade - General physical (natural) geography of continents and geography of countries in Africa and Australia. } \\
\mathbf{6}^{\text {th }} \text { grade - General physical (natural) geography of Europe, Asia, America with brief information on the major countries in them }\end{array}$ \\
\hline 1990 & $\begin{array}{l}\mathbf{5}^{\text {th }} \text { grade - Selected Questions in general physical geography. Geography of the continents Africa, South and North America. } \\
\mathbf{6}^{\text {th }} \text { grade - Geography of continent Europe (with extensive exploration of the Balkan peninsula and Bulgaria), Asia, Australia (with } \\
\text { Oceania), Antarctica. }\end{array}$ \\
\hline 1994 & $\begin{array}{l}\mathbf{6}^{\text {th }} \text { grade - Geography of the continents Africa, South America, North America, Asia, Australia and Oceania, Antarctica. } \\
7^{\text {th }} \text { grade - Geography of Europe, Balkan peninsula and Bulgaria. }\end{array}$ \\
\hline 2009 & $\begin{array}{l}\mathbf{6}^{\text {th }} \text { grade - Geography of continents and oceans (Africa, Atlantic ocean, South America, North America, Arctic Ocean). } \\
\mathbf{7}^{\text {th }} \text { grade - Geography of continents and oceans (Asia, Indian ocean, Australia, Pacific, Oceania, Antarctica). } \\
\mathbf{8}^{\text {th }} \text { grade - Geography of continent Europe, Balkan peninsula and Bulgaria. }\end{array}$ \\
\hline
\end{tabular}


Geography and economics training for grades 5 - 7 is aimed at meeting the modern requirements for geographic education for:

$\rightarrow$ perception the student as the main focus that concentrates on the nature of training as a systematic process;

$\rightarrow$ creation of psycho - didactic comfort for unfolding his initiative;

$\rightarrow$ stimulating the expression of personal position and attitude on studied topical questions that have a geographical projection;

$\rightarrow$ formation of sustainable social competences for tolerance in communication through dialogue and teamwork;

$\rightarrow$ providing a qualitative model for the perception of geographical knowledge in a system that will allow the creation of its own learning strategy;

$\rightarrow$ stimulating an analytical and critical thinking to allow flexible behavior against the complex and rapidly changing reality;

$\rightarrow$ formation of skills for reasoned solving of cognitive and practically - applied problems;

$\rightarrow$ formation of a value system, parallel to the impact of social and family determinants.

Despite this multifaceted nature, undoubtedly the main function of curricula is to parameterize of the school content.

The classical approach to its decomposition is: leading ideas, knowledges (theoretical, factual, methodological) and skills (practical and intellectual). These basic content components are presented in varying degrees of detail in geography and economics curricula for 5 - 7 grade depending on the general strategy of geographic training in the Bulgarian school and the psycho - physiological age characteristics of the students.

The guiding ideas are related to the peculiarities of the geographical knowledge. They are generalizations that have great cognitive value. Mastering them contributes to the formation of a value attitude.

The knowledges are theoretical (theories, regularities, general concepts), methodological and empirical (ideas, facts). They are the link between the basics of geographical knowledge and the skills to perceive it in an ontodactic projection (adapted to the cognitive potential of the learners).

The skills are the other major component in the school content of geography. They are „student-led mental or practical actions aimed at solving specific learning tasks“ (Gaitandzhieva, 2000).

The attachment, of the three main components in the requirements for the training of the class - level in the curricula, implies the formation of a qualitative emotional - value attitude to the natural and social reality. The requirements for achieving general education preparation in each subject - expected competences (knowledges, skills and attitudes) are as a results of the training in each general subject at the end of the stage and their connection to the key competences.

\subsection{CONCEPTUAL FRAMEWORKS FOR THE SCHOOL SUBJECT OF GEOGRAPHY AND ECONOMICS IN 5TH GRADE}

The school subject of Geography and economics has an integral character, which is understood by the fact that the content of the curricula combines information and methods of knowledge from different fields. This allows for a unified picture of nature and the place of man in it. Teaching geography in the first self - contained course in Geography and economics in 5 grade is a didactic challenge for every teacher. In its conceptual essence, the course is a natural continuation of the propedeutic knowledges acquired by the students in primary school degree.

Its fundamental importance for the integrity of the geographic training system is complemented by the fact that it is directly or indirectly linked to the content of the educational geography at the junior high school and the high school stage through the fundamental knowledges, skills and competences that it forms.

At the beginning, with a brief presentation of the curricula, the is formulated the following: „Geography and economics training in 5th grade aims to master basic knowledges, skills and acquiring key competences related to forming the foundations of geographical culture for the surrounding area at a global and regional level as part of their common culture“ (Uchebna programa - V klas, 2015). 
The first self - contained course „Geography and economics“ in the $5^{\text {th }}$ grade marks the beginning of geography education in the Bulgarian secondary school. Because of this, the criticality to his philosophy is further exacerbated and most often provokes strong resistance in any attempt to reform.

In its conceptual nature, it is a natural continuation of the propedeutical knowledge acquired by students in primary school degree in the subjects „Man and Nature“ and „Man and Society“ in grades 3 and 4.

The general and regional (due to the inclusion of Africa and Antarctica) character of the course is differentiated by its main content - themed nuclei: Earth as part of the Solar system, the natural appearance of the planet, population, settlements, political map, economy and two continents. It responds to the modern concepts of the trinity of geographical science with regard to the nature - society - economy interaction and the uniqueness of its manifestation in clearly distinct regional units with contrasting characteristics. The knowledges, skills and attitudes as expected training results for each school subject are listed in the respective curriculum.

The cognition center is the general concepts whose consequence (despite the attempts at optimization) is the substantial theoretical workload. They are related to the geographical map, the territorial units of the earth surface (continents and oceans), the natural components, the demographic and socio - economic characteristics of the planet, with an accent on mastering, understanding of their essential features and awareness of their importance. The location of the school course is determined by a system of factors, among which the following can be identified as key:

Bo the logic and the achievements of geographical science, adapted through modern didactic concepts of training and learning;

to the established and already traditional geographic training start with a deductive elementary course on which to build the regional courses;

to the opportunities to pursue interdisciplinary integration with primary and secondary school subjects such as: Man and Society, Man and Nature, Mathematics, History and Civilizations, Technology and Entrepreneurship, and others;

to the age psycho - physiological characteristics of the students, which are characterized by curiosity, interest in a new, engaged and motivated attitude to the learning process.

\subsection{CURRICULUM IN GEOGRAPHY AND ECONOMICS IN $6{ }^{\mathrm{TH}}$ GRADE - PREREQUISITES FOR THE REALIZATION OF KEY COMPETENCES}

The study of geography and economics in the $6^{\text {th }}$ grade on the basis of interaction and interdependence, territories and common problems, characterized by specific development and policy, is evidence of school geography as one of the school subjects with a broad outlook on the global problems and sustainable development, on dynamics of economic development and controversy.

The expected results of the $6^{\text {th }}$ grade training for general education preparation at the end of the class related to the main area of competence: Geography of continents and countries and the acquisition of knowledges, skills and attitudes to: explore the world and the development of the geographical knowledge; geographical location and borders, nature of oceans and continents: South and North America, Asia, Australia; political map, population, economy in South and North America, Asia, Australia, Oceania and selected countries (Brazil, Argentina, USA, Canada, Japan, China, Turkey, Republic of Korea, The Australian Union and New Zealand). The other major area of competence is related to geographical information.

The content - structural analysis of the current regulatory framework governing modern training in geography and economics in the $6^{\text {th }}$ grade shows that it should not only formally conform to the logic of geographical and didactic science, but also to comply with the traditions and proven practices. The conceptual solution is a consequence of defining the system-forming (integrating) idea around which substantive and structural training in geography and economics is built in 6 grade which suggests:

- overcoming the dissonance between the ever - increasing information flow and the reshaped requirements for students' knowledges, skills and competences with respect to their potentialities;

- compliance with the content, information and structural accents of the training course in order to develop geographical skills and their application in various didactic situations; 
- facilitating the process of comprehending the school content by refining factual loading and formalism;

- designing the learning process in an effective learning environment and training environment;

- connecting in the organic system of the information - content, organizational - activity and emotionally - motivating side of the training;

- organization of individual, group and team (in the case of pre - group distribution of roles) and in cooperation with each other form of study activity depending on the didactic goals;

- expanding the area of activity of learners by including them in different types of intellectual and applied interactions with sources of information on one hand and on the other participants in the training process (teacher, classmates) on the other;

- concentric deployment of diverse and thematically focused, but in the same time interconnected school activities of increasing complexity, in a complex, build a system of cognitive, psycho - motor and affective mechanisms for a competency approach;

- reflexive self - organization of the process of mastering skills based on their relation towards external assessment and self - assess and confidence in their theoretical and practical value.

Geography and economics training in $6^{\text {th }}$ grade aims to continue the formation and development of geographical culture by mastering basic knowledges, skills and acquiring key competences for the surrounding area at regional level by studying selected continents and oceans on the planet (Uchebna programa - VI klas, 2016). The $6^{\text {th }}$ grade course is a natural continuation of the general and regional (due to the inclusion of Africa and Antarctica) character of the $5^{\text {th }}$ grade course, which is distinguished by its basic content - themed nuclei: Earth as part of the Solar system, the natural appearance of the planet, the population, settlements, political map, economy and two of the continents.

It is established logic and consistency in the formation of the knowledges on every continent. The content has been developed into two main themes: 1) for the nature of the continent; 2) for the continent's population, economy and political map. Complex system concepts are formed for the geographical objects: on four continents and five oceans.

Applying a competency approach to geography and economics training in 6 grade leads to the understanding and characterization of geographical position, nature, political map, population, economy and in selected countries in South and North America, Asia, Australia and Oceania.

\subsection{THE EDUCATIONAL PROCESS AND THE NEW CURRICULA IN GEOGRAPHY AND ECONOMICS IN $7^{\mathrm{TH}}$ GRADE}

The new curricula in geography and economics requires students to become familiar with continent Europe, the Balkan peninsula and Bulgaria as part of their $7^{\text {th }}$ grade education. The main objective is , aimed at mastering basic knowledges, skills and acquiring key competences related to Europe, the Balkan peninsula and Bulgaria" (Uchebna programa - VII klas, 2017).

The curricula contains three areas of competences - Geography of continents and countries, Geography of Bulgaria and Geographic information, each for which the expected results for knowledges, skills and attitudes from training to achieve general education at the end of class. The curricula identifies 12 major themes for the study of Europe's geography within 1/3 of the study time. The logical structure of educational content in geography and economics in the $7^{\text {th }}$ grade is normatively defined: Geographical position, borders, size and coast of Europe; Relief; Minerals; Climate; Water; Wildlife areas; Population; Political map; Ecomomy; Countries in Europe.

The training includes characterization of geographical location and borders, peculiarities of nature, political map, population and economy of Europe, of selected countries or of specific countries - Germany, Great Britain, France, Italy, Sweden, Russia.

The most applicable topics in the curricula on themes are the active verbs for conceptual knowledge. Through the active verbs of understanding and application, students form knowledges, skills and relationships between the various parts of the overall structure in a continent algorithm that promotes knowledge of a single whole - the geography of Europe. 
Active verbs are used for understanding - explains, gives examples and understands, and for application - applies, characterizes, compiles, presents, works (Dermendzhieva, Sabeva \& Dimitrova, 2010). There are three main aspects of active verbs in training for countries in Europe: grouping countries by territorial principle, characterizing a country by rule, and presenting a country through different forms (text, poster, presentation) - figure 2 (Uchebna programa - VII klas, 2017; Dermendzhieva \& Draganova, 2018).

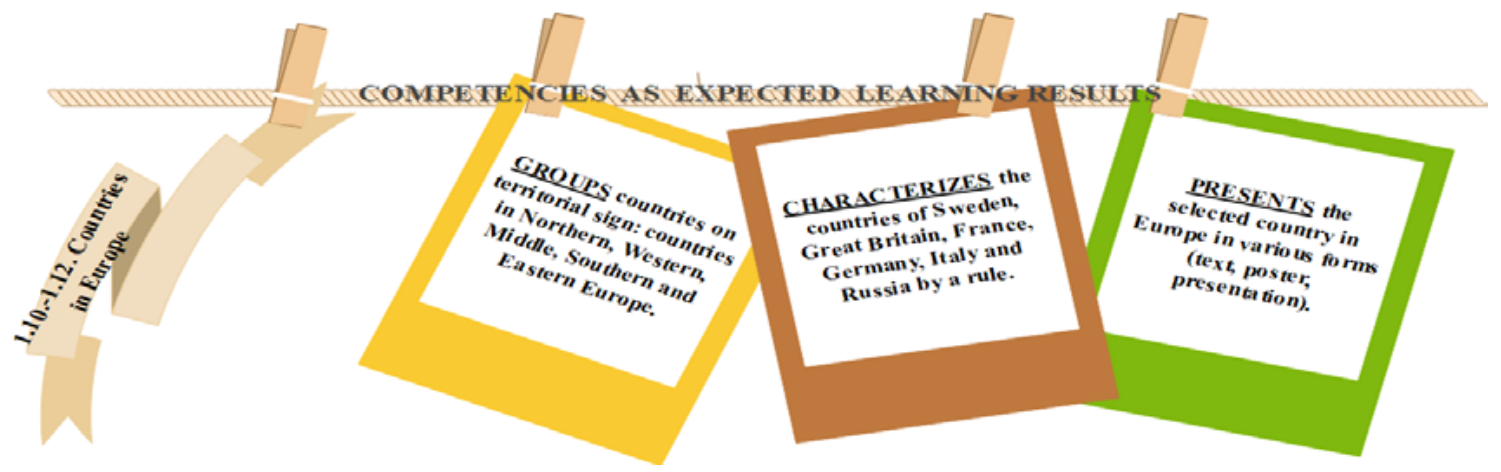

Figure 2: Competencies as expected results in studying the European countries

A new element in the structure of the curricula in the Bulgarian school is the recommended percentage allocation of the compulsory school hours. In the $7^{\text {th }}$ grade, lessons for new knowledges, for exercises (activities), for summarization and for control works are applicable in the new realities of studying geography of Europe - Figure 3.
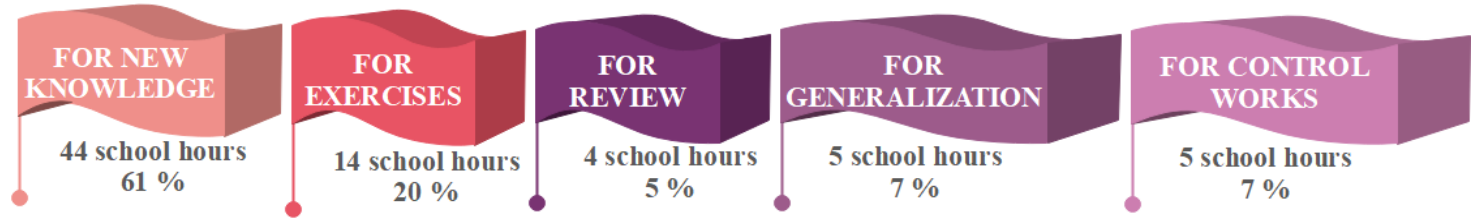

Figure 3: The recommended percentage allocation of the compulsory school hours $-7^{\text {th }}$ grade

The study of geography of Europe in $7^{\text {th }}$ grade is based on the expanded vertical connections of $5^{\text {th }}$ and $6^{\text {th }}$ grade, which develop students ${ }^{6}$ knowledges, skills and attitudes in the final regional course. The curricula provides consistency and inter-connectivity of the structural components. The activities in the general education preparation have been identified in line with the key competences groups of the European reference framework (Uchebna programa - VII klas, 2017; Dermendzhieva \& Draganova, 2018).

Inter - disciplinary links in the new curricula have been significantly increased in number and content with a specific content framework across key competencies - figure 4. For each inter - disciplinary link is determined the name of the school subject and its activities through which it can be realised.

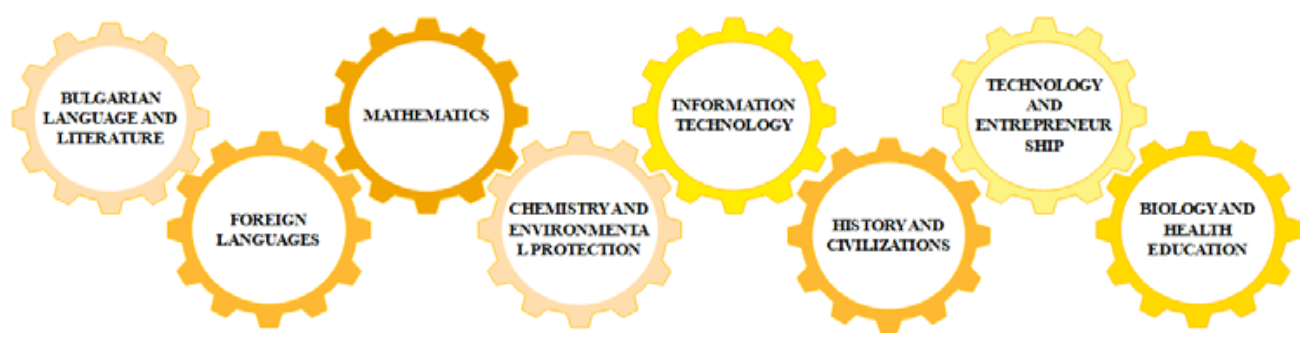

Figure 4: Inter - disciplinary links in Geography and economics - 7 grade

Geography and economics training in $7^{\text {th }}$ grade has a key perspective importance for the geographical training system. The quality implementation means predictable effectiveness with increasing affinity for creativity on the part of teachers and students due to the freedom to use algorithmic acquired knowledge of the characteristics of the territory and the skills to apply them. And the contrary, „templateization”, the mechanical learning of rules and standart plans can cause a stereotyping, which leads to an indifferent effect in the study of geography and economics. 


\section{CONCLUSION}

The school geography in junior high school stage in grades $5-7$ has enormous potential for building and developing those key competencies that underpin in the basic of the functional literacy. Competencies, defined as knowledges, skills, attitudes, and values, lead to the attachment of individual personality abilities with social goals and can contribute to successful personal, professional and social realization. Geography prepares the students for active civic life, successful tackling the labor market and in a knowledge-based society. This stems from its subject, which enables the formation of knowledges and skills not only for nature or society, but also for the relationships and interactions between nature - society - economy. In this sense, geography-specific competences are formed - to detect dependencies and influences, to explain and predict phenomena, to apply models from one sphere to another, to recognize the manifestations of physical laws in nature, to form civic and cultural competences, and others.

With the optimal combination of the necessary didactic conditions (detailed study of the educational documentation and compliance with its requirements; appropriate selection of textbooks and educational aids, informatization and technology, pursuant to the specificities of the particular school environment), and application of the principles of humanization, sociology, dynamization of the interaction between teacher and students in the course of educational activities, the social expectations for geographical training would be achieved.

\section{REFERENCES}

Zakon za preduchilishnoto i uchilishnoto obrazovanie, ZPUO. (2015). Bulgaria.

Gaitandzhieva, R. (2000). Strategiya na geografskoto obrazovanie v srednoto uchilishte pri novite realnosti. Sofiya, IK Anubis, p. 18.

Uchebna programa po geografiya i ikonomika za V klas (obshtoobrazovatelna podgotovka). (2015).

Uchebna programa po geografiya i ikonomika za VI klas (obshtoobrazovatelna podgotovka). (2016).

Uchebna programa po geografiya i ikonomika za VII klas (obshtoobrazovatelna podgotovka). (2017).

Dermendzhieva, S., P. Sabeva, B. Dimitrova. (2010). Geografiya i obrazovanie. Metodika na obuchenieto po geografiya, I chast. V. T., UI „Sv. sv. Kiril i Metodii”, p. 371.

Dermendzhieva, S., Draganova, T. (2018). How the „Geography of Europe” subject is studied in new educational realities - following the Bulgarian secondary school model. - In: The overarching issues of the European space, Porto, University of Porto, pp. 54 - 71. 